Author version: Nat. Hazards: 49(2); 2009; 411-420

\title{
Demarcation of inland vessels' limit off Mormugao port region, India: a pilot study for the safety of inland vessels using wave modelling
}

\author{
P.Vethamony, V.M. Aboobacker, K. Sudheesh, M.T. Babu and K. Ashok Kumar \\ National Institute of Oceanography \\ Dona Paula, Goa -403004, India
}

\begin{abstract}
The Ministry of Shipping desires to revise the inland vessels' limit (IVL) notification based on scientific rationale to improve the safety of vessels and onboard personnel. The Mormugao port region extending upto the Panaji region has been considered for the pilot study. Measured wind and wave parameters off Goa have been analysed. AWS winds, moored buoy winds, NCEP re-analysed winds and NCMRWF winds are used as input to regional and local models. The wave model results are validated with measured significant wave heights and shows good comparison. The analysis indicates that the significant wave heights never exceeded $2.0 \mathrm{~m}$ during the non-monsoon months. However, the wave heights during monsoon months exceeded 5.0m, and even upto $7.0 \mathrm{~m}$ during extreme events. In order to draw the IVL lines, the local model has been set up and simulated the nearshore waves off Goa during May 2004 - May 2005 considering the offshore wave parameters from the regional model at the boundary and the winds measured using AWS as well as deep water buoy moored off Goa. The nearshore region off Goa has been classified based on significant wave height values and accordingly the IVL lines have been fixed for the Mormugao Port and Panaji coastal regions.
\end{abstract}

Keywords: Mormugao Port, wave modelling, wave measurement, MIKE 21, inland vessels' limit, wave spectra

\footnotetext{
* Corresponding author. Tel.: 91832 2450473. Fax: 918322450604

Email addresses: mony@nio.org (P.Vethamony)

vmabacker@gmail.com (V.M.Aboobacker)

ksudheesh@nio.org (K.Sudheesh)

mtbabu@nio.org (M.T.Babu)

akumar@nio.org (K.Ashok kumar)
} 


\section{Introduction}

Information on winds and waves are very essential for activities such as exploitation of natural resources, ship-routing, design of harbours, breakwaters and jetties, loading and unloading of products to and from the vessels and navigation of different types of vessels in the coastal region. Until a few years ago, the lack of adequate reliable wind and wave data had been recognised as a major limiting factor to such activities along the Indian coast, including port and harbour regions.

The Ministry of Shipping desires to revise the IVL (inland vessels' limit) notification based on scientific rationale for the following reasons: area of operation of ports has been extended towards the offshore and (ii) new major and minor ports have been developed since 1972. One of the objectives of this initiative is to improve the safety of vessels and onboard personnel. This limit is necessary to prevent the damage to any vessel or loss of life.

Figure 1 shows the study region including the Mormugao Port limit. Mormugao bay lies between Mormugao Point ( $\left.15^{\circ} 25^{\prime} \mathrm{N}, 73^{\circ} 47^{\prime} \mathrm{E}\right)$ and Cabo Point. The south of the Mormugao bay is mostly rocky rising upto the tableland of Mormugao Head. The port of Mormugao, protected by a breakwater lies on the north of Mormugao Head. The Cabo point is a prominent headland, $55 \mathrm{~m}$ high. The north of Mormugao Bay between Cabo point and Nazaret point consists of alternating stretches of sand and rock.

The port of Mormugao is formed by a breakwater and a mole. It provides 11 alongside berths and several mooring buoys. During the southwest monsoon, when pilots cannot embark, a launch will lead vessels from the breakwater head to a suitable anchorage. Anchorage may be obtained in depths of about $7 \mathrm{~m}$. Small vessels may anchor in Vasco Bay in a depth of about $4 \mathrm{~m}$.

The ebb stream sets strongly out of Mandovi river, but is weak at the anchorage off Aguada Head, where the flood stream is barely perceptible. The Mandovi river flows into the head of Aguada Bay. The bar at the Mandovi river mouth is subject to frequent change. During southwest monsoon, large breakers break across the bar and river mouth, and makes navigation in and out across the mouth very difficult.

The present work is primarily concerned with significant wave heights of the region off Mormugao port. Measurements along with numerical wave modelling offer an effective way to contribute substantial information on wave parameters. AWS winds, moored buoy winds, NCEP analysed winds and NCMWRF winds are used as input to MIKE 21 - OSW and NSW models. The wave model results are validated with wave parameters measured using moored data buoys and directional wave rider buoys at different times. 


\section{Data and Methods}

Wave data measured using directional wave rider buoy and moored buoys at various locations off Goa during different measurement periods are used to analyse the wave characteristics of the region. In order to get an overall picture of the waves off Goa, the wave data measured off Mormugao during February 1996 May 1997 are analysed. The waves measured off Goa during May 2005 at two locations having water depths $25 \mathrm{~m}$ and $15 \mathrm{~m}$ are used to study the wave transformation and to analyse the effect of local winds on the generation of wind seas over the region. Moored buoy data, which consists of wind and waves, at deep water location during July - November 1999, May - July 2000, January 2001 and May - September 2001 and at shallow water location during May - September 2001 and October 2004 - March 2005 are also utilised in this study.

The wind measured using AWS (Autonomous Weather Station) located at Dona Paula coastal station during May - September 2004 and April - May 2005 were analysed to study wind characteristics off Goa during pre-monsoon and south west monsoon periods.

In order to predict the offshore waves in the North Indian Ocean, the winds from NCEP (National Centre for Environmental Prediction, USA) re-analysis (Kalnay et al., 1996) and NCMRWF (National Centre for Medium Range Weather Forecasting) were utilised. The duration of NCMRWF wind is July - August 1999, May - July 2000 and May - September 2001, where as it is May 2004 - June 2005 for NCEP winds. NCEP winds available in $2.5^{\circ} \times 2.5^{\circ}$ grids in the form of $\mathrm{U}$ and $\mathrm{V}$ components for different periods have been extracted and linearly interpolated to $0.75^{\circ} \times 0.75^{\circ}$ grid size as the resolution for the offshore model bathymetry is considered as $0.75^{\circ} \times 0.75^{\circ}$ grid size. NCMRWF winds are available in $1.5^{\circ} \times 1.5^{\circ}$ grid size for every six hour interval in the form of $\mathrm{U}$ and $\mathrm{V}$ components. These winds are also converted into resultant winds in $0.75^{\circ} \times 0.75^{\circ}$ grid size. To ascertain the accuracy of NCEP winds, the re-analysis winds of May August 2000 have been compared with the buoy wind data off Goa, Kochi and Chennai. Vethamony et al (2003) and Sudheesh et al (2004) were used NCMRWF and NCEP winds in MIKE 21 OSW to generate the offshore waves; however the comparison with measured wave parameters shows good match. It has been validated by Tolman (1998) to utilise the NCEP re-analysed winds in the offshore wave prediction models.

Offshore and nearshore wave modelling has been carried out using MIKE 21 OSW (Offshore Spectral Wave) and MIKE 21 NSW (Nearshore Spectral Wave) models developed by DHI Water \& Environment, Denmark (DHI, 2001), respectively for North Indian Ocean (Regional model) and off Goa (local model) regions.

MIKE $21 \mathrm{OSW}$ is a discrete spectral model, which describes the wave field by the directional-frequency wave energy spectrum. The energy is calculated in discrete points of a rectangular grid for a number of 
discrete frequencies and directions. The model includes two different descriptions of physical processes governing the wind-wave generation and decay: state-of-the-art third generation formulation and second generation formulation. The third generation model is based on the internationally developed WAM Cycle 4 model originally developed for deep-water application on global and regional scale. The model is based on the numerical integration of the spectral energy $(F)$ balance equation formulated in Cartesian co-ordinates

$$
\frac{\boldsymbol{D F}}{\boldsymbol{D} \boldsymbol{t}}=\mathrm{S}_{\text {wind }}+\mathrm{S}_{\text {nonlinear }}+\mathrm{S}_{\text {bottom-dissipation }}+\mathrm{S}_{\text {white-capping }}+\mathrm{S}_{\text {wave-breaking }}
$$

The left-hand side describes the wave propagation in time and space using linear wave theory. The righthand side represents the superposition of source functions describing various physical phenomena. Wavewave interaction, refraction, and dissipation due to breaking are included in this model. The basic input parameters to the model are bathymetry and wind fields. The model domain is divided into different grids and input parameters are provided at each grid point. Time step corresponding to the Courant Number is chosen, keeping the minimum wave period present.

MIKE $21 \mathrm{NSW}$ is a stationary, directionally de-coupled parametric model. To take into account the effect of current, the basic equations in the model are derived from the conservation equation for the spectral wave action density. The model takes into account the effects of refraction and shoaling due to varying depth, local wind generation and energy dissipation due to bottom friction and wave breaking. The model also takes into account the effect of wave-current interaction.

The basic equations are solved using an Eulerian finite difference technique. The zeroth and the first moment of the action spectrum are calculated on a rectangular grid for a number of discrete directions. A oncethrough marching procedure is applied in the predominant direction of wave propagation.

The bathymetry for the regional model has been generated using ETOPO5 bathymetry data obtained from NGDC (National Geophysical Data Center, Colorado, USA), representing the best available bathymetry values spaced at every five-minute latitude / longitude. The model domain covers the region $5^{\circ} \mathrm{S}$ to $25^{\circ} \mathrm{N}$ and $45^{\circ} \mathrm{E}$ to $100^{\circ} \mathrm{E}$ and the domain is divided into $0.75^{\circ} \times 0.75^{\circ}$ grid size. The depth values are provided at all the grid points.

The bathymetry for the local model has been generated using the water depths extracted from C-MAP electronic chart database of MIKE 21 for the domain extends from $15^{\circ} 18^{\prime} \mathrm{N}$ to $15^{\circ} 36^{\prime} \mathrm{N}$ and $73^{\circ} 36^{\prime} \mathrm{E}$ to $73^{\circ} 55^{\prime} \mathrm{E}$. The grid spacing is $200 \mathrm{~m} \times 50 \mathrm{~m}$. The bathymetry data are with reference to WGS 84 . 
Winds measured at Dona Paula coastal station using AWS during May - September 2004 and April - May 2005 and the data measured off Goa using moored buoy during October 2004 to March 2005 were utilised in the nearshore wave modelling. The wave parameters at the boundary of local model is extracted from the regional model outputs, which further applied in the local model as boundary conditions along with the AWS winds. The nearshore wave simulation in the local model has been carried out during May 2004 to May 2005.

The basic output of the model is significant wave height, wave period, wave direction and directional spread. The wave model results are validated with wave parameters measured using moored data buoys and wave rider buoys at different times. The moored buoy data are available at every $10 \mathrm{~min}$. interval and the model results were extracted at the point of location of the moored buoy for every $3 \mathrm{~h}$ interval. Therefore, the buoy data were averaged for $3 \mathrm{~h}$ to compare with the model results. The wave rider data available for every $20 \mathrm{~min}$., was also averaged fro $3 \mathrm{~h}$ to compare with the model results.

The nearshore wave transformation has been simulated considering the measured wave parameters at $25 \mathrm{~m}$ location as the boundary during 01 - 21 May 2005. The significant wave height at $15 \mathrm{~m}$ location has been extracted from the model results and compared with the measured data at this location.

Significant wave heights derived from different sources in and around the coastal region off Goa have been used to draw IVL limit as follows: (i) regions where significant wave heights ( $\mathrm{SWH})<0.6 \mathrm{~m}$, (ii) regions where $0.6 \mathrm{~m} \leq \mathrm{SWH} \leq 1.2 \mathrm{~m}$ and (iii) regions where $1.2 \mathrm{~m} \leq \mathrm{SWH} \leq 2.0 \mathrm{~m}$.

\section{Results and Discussion}

It has been found from the analysis of the AWS winds during May - September 2004 and April - May 2005 that the locally generated winds are prominent during pre-monsoon periods (April and May) and there exists diurnal variations in wind speed and direction due to sea breeze and land breeze systems. The winds during the southwest monsoon (June - September) are higher and it would generate the waves with larger wave heights.

It is evident from the comparison between NCEP reanalysis winds and measured winds off Goa, Kochi and Chennai that NCEP winds match closely with buoy winds, though at times they are marginally higher than the buoy winds.

The analysis of the waves measured off Goa during February 1996 - May 1997 shows that the significant wave height varies from $0.16 \mathrm{~m}$ to $5.85 \mathrm{~m}$ throughout the measurement period. Highest significant wave height of $5.85 \mathrm{~m}$ and highest maximum wave height of $10.47 \mathrm{~m}$ were observed in June 1996 when a monsoon depression was formed over Arabian Sea. The mean crossing period predominantly varied from 3 to $9 \mathrm{~s}$ 
during the measurement period. Table 1 shows the monthly variations in the significant wave height and mean wave period off Goa during the measurement period.

In order to identify the wave characteristics off Goa, when the existence of sea breeze becomes predominant, the measured waves at 25m and 15m water depths off Mormugao during 1 - 21 May 2005 and 6 - 20 May 2005 respectively were analysed. Significant wave height varies from 0.56 to $1.26 \mathrm{~m}$ and 0.54 to $1.16 \mathrm{~m}$, while mean wave period varies from $4.4 \mathrm{~s}$ to $9.3 \mathrm{~s}$ and $4.4 \mathrm{~s}$ to $8.6 \mathrm{~s}$ at $25 \mathrm{~m}$ depth and $15 \mathrm{~m}$ depth locations respectively. Wave transformation occurred due to refraction, shoaling and bottom friction is very evident from the analysis of the wave parameters at both the locations.

The influence of locally generated wind over the waves off Goa has been analysed by comparing the patterns observed in the distribution of wave heights and wave periods at $15 \mathrm{~m}$ and $25 \mathrm{~m}$ water depths. It has been observed that whenever the wind speed increases, wave height also increases, but wave period decreases; vice versa, when wind speed decreases. This is due to the super-imposition of wind seas, which is generated due to sea breeze, over the pre-existing swells. This shows the influence of locally generated winds over the wave characteristics of the region during pre-monsoon periods.

Wave spectra for 13 May 2005 (every $3 \mathrm{~h}$ interval) plotted for understanding the wave transformation are shown in Figure 2. Similar spectra were observed in all days of the measurement period. Two major multipeaks observed in the wave spectra at two different frequency bands can be attributed to wave trains coming from two different directions. This is a combination of short period wind seas generated due to local winds and the long period swells which are generated far away and propagating towards the region. Rao and Baba (1996) also observed the muti-peakedness and the diurnal variations in the wave spectra off Goa during a pre-monsoon period. Vethamony and Sastry (1986) also studied the multi-peakedness of the waves when there exists locally generated wind seas. It is evident from the close analysis of the local winds measured at coastal station and the wave spectra measured off Goa that the diurnal variations in the wave parameters are mainly due to the co-existence of locally generated wind seas over the pre-existing swells.

Waves simulated in the regional model with NCMWRF winds during May-August 2000, have been compared with the wave parameters measured in the deep water buoy off Goa. The higher winds, of the order of $15-18 \mathrm{~m} / \mathrm{s}$, and higher wave heights, of the order of $3.5-4.5 \mathrm{~m}$, were observed during 5-7 June 2000 at the deep water location off Goa. Indian Daily Weather Report (2000) indicated the presence of lowpressure system during the period, and the observed higher winds and wave heights are due to this extreme event occurred at the region. The modeI responded well with simulation of the extreme events even with coarse resolution winds for the offshore wave prediction. 
The regional model also simulated the wave parameters during July - November 1999 and May - September 2001. The results are compared with the measured data of deep water buoy (DS1) and shallow water buoy (SW3) deployed off Goa. Figure 3 shows the validation of modelled significant wave height with measured waves at deep water location off Goa during August 1999.

Table 2 shows the statistical relations between the comparison such as bias, rms error and correlation coefficient at various locations during different periods. Further, comparison between modelled and measured wave heights is presented as scatter plots in Figure 4. It has been observed that the wave heights during monsoon months exceed $5.0 \mathrm{~m}$, and when extreme event occurs, it can even exceed $7.0 \mathrm{~m}$. In general, SWHs $>2.5 \mathrm{~m}$ during May-September are typical for monsoon wave characteristics.

The correlation coefficients $(\gamma)$ for modelled and measured wave heights are in the range of 0.87 to 0.92 . The same for modelled and measured wave periods is in the range of $\gamma=0.68$ to 0.77 . In general, match is reasonably good for wave period also. Wave periods are of the order of 6-9 s during June and July 2001 and of the order of 4-8 s during May, August and September 2001. Wave characteristics clearly indicate that the Arabian Sea (and so off Goa) is under the influence of southwest monsoon waves during June-September, and are dominated by 'seas', - typical of monsoon months.

The nearshore waves simulated in the local model for the period May 2004 - May 2005 gives a clear picture about the nearshore wave distributions over the region for a period of a year. The simulated significant wave height is compared with the measurements and shows good comparison between them. The nearshore waves simulated in the local model during 01 - 21 May 2005 by considering the measured waves at $25 \mathrm{~m}$ depth as the boundary has been validated. The significant wave height extracted at $15 \mathrm{~m}$ depth location shows good comparison with the measured significant wave height during the period (Figure 5).

It has been observed from the model results that range of significant wave height was exceeded $2.5 \mathrm{~m}$ during June - August 2004, where as it is below 2.0m during September and not exceeded $1.2 \mathrm{~m}$ during October 2004 - May 2005. Based on the distribution of significant wave heights off the region, the inland vessels' limit is revised. Figure 6 shows the typical significant wave height distribution off Mormugao Port during southwest monsoon. It is very clear that most of the regions are influenced by large monsoon waves having significant wave height greater than $2.5 \mathrm{~m}$.

Table 3 shows the statistics of the significant wave height exceeded $2.0 \mathrm{~m}$ during southwest monsoon on various years of measurement. It shows the occurrence of the significant wave heights greater than $2.0 \mathrm{~m}$ are higher during June - August. Table 4 shows the ranges of significant wave heights derived from available moored buoy data off Goa. The higher values of significant wave height are obtained during June - August in all years, though the highest value of $4.30 \mathrm{~m}$ obtained in May 2001 due to extreme event prevailed in the 
region. In all other months, the significant wave heights are obtained below $2.0 \mathrm{~m}$. Hence it is very evident that Mormugao Port and Panaji coastal region are safe from large waves throughout the year except during June - August, where as larger waves can be expected if there exists any extreme events on the region.

\section{Conclusion}

The significant wave height values obtained from the nearshore wave model as well as wave measurements conducted off Goa during different years indicates that during non-monsoon months (October - May) and in September, significant wave heights do not exceed $2.0 \mathrm{~m}$ off the Mormugao Port and Panaji coastal regions. During monsoon months (June - August), the significant wave height crossed $2.5 \mathrm{~m}$ in most of the regions, hence the coastal operations would not be possible during the season. Based on the significant wave heights distributed over the region throughout the year, the inland vessels' limit is revised and demarcated.

\section{Acknowledgments}

We thank Dr SR Shetye, Director, National Institute of Oceanography (NIO), Goa for providing necessary facilities. 


\section{References}

IMD (2000) Indian Daily Weather Report, India Meteorological Department, Pune, India.

DHI (2001) MIKE 21 Wave modelling user guide, DHI Water \& Environment, Denmark, 66 pp.

Kalney E; Kanamitsu M; Kistler R; Collins W; Deaven D; Gandin L; Iredell M; Saha S; White G; Woollen J; Zhu Y; Chelliah M; Ebisuzaki W; Higgins W; Janowiak J; Mo K.C; Ropelewski C; Wang J; Leetmma A; Reynolds R; Jenne R; Joseph D (1996) The NCEP/NCAR reanalysis project, Bull. Am. Meteorol. Soc., 77, 437- 471.

Rao C.V.K.P., Baba M. (1996) Observed wave characteristics during growth and decay: a case study. Continental Shelf Research 16 (12), 1509-1520.

Sudheesh K., Vethamony P., Babu M.T., JayaKumar S. (2004) Assessment of wave modeling results with buoy and altimeter deep water waves for a summer monsoon. Proceedings of the Third Indian National Conference on Harbour and Ocean Engineering (INCHOE - 2004). NIO, Goa (India). pp 184-192.

Tolman H.L (1998) Validation of NCEP's ocean winds for the use in wind wave models, Global Atmos. Oc. System, Vol. 6, pp. 243-268.

Vethamony P; Sastry, J.S. (1986) On the characteristics of multipeaked spectra of ocean surface waves. J. Inst. Eng. India, 66, 129-132.

Vethamony P; Sudheesh K; Asha Rajan; Saran A.K; Sujit Basu; Raj Kumar; Abhijit Sarkar (2003) Wave modelling using MSMR analysed winds, Report No. NIO/TR/10/2003, February 2003, National Institute of Oceanography, Goa, India.

Vethamony P; Sudeesh K; Rupali SP; Babu MT; Jayakumar S; Saran AK; Basu SK; Kumar R; Sarkar A. (2006) Wave modelling for the north Indian Ocean using MSMR analysed winds. Int. J. of Remote Sensing, 27(18), 3767-3780. 
Table 1 Monthly variations in the significant wave height and mean wave period off Goa during February 1996 - May 1997.

\begin{tabular}{|c|c|c|c|}
\hline Year & Month & $\begin{array}{l}\text { Significant wave } \\
\text { height }(\mathrm{m})\end{array}$ & $\begin{array}{l}\text { Mean wave } \\
\text { period (s) }\end{array}$ \\
\hline \multirow[b]{11}{*}{1996} & February & $0.33-1.50$ & $3.0-5.0$ \\
\hline & March & $0.42-1.82$ & $3.0-5.7$ \\
\hline & April & -- & -- \\
\hline & May & $0.75-1.37$ & $3.7-6.3$ \\
\hline & June & $0.93-5.85$ & $4.6-9.1$ \\
\hline & July & $1.32-4.29$ & $5.2-8.7$ \\
\hline & August & $1.20-3.25$ & $4.4-7.5$ \\
\hline & September & $0.80-1.80$ & $4.1-8.0$ \\
\hline & October & $0.47-3.31$ & $3.6-6.9$ \\
\hline & November & $0.36-1.20$ & $3.1-6.5$ \\
\hline & December & $0.29-0.96$ & $2.7-6.5$ \\
\hline \multirow[b]{5}{*}{1997} & January & $0.27-1.65$ & $2.7-5.6$ \\
\hline & February & $0.38-1.39$ & $3.1-5.3$ \\
\hline & March & $0.39-1.77$ & $3.1-5.7$ \\
\hline & April & $0.16-1.50$ & $2.8-5.7$ \\
\hline & May & $0.38-1.36$ & $2.9-6.1$ \\
\hline
\end{tabular}

Table 2 Correlation coefficients $(\gamma)$, bias and rms error between model and measured significant wave height and mean wave period at moored buoy locations

\begin{tabular}{|l|l|l|l|l|l|l|l|}
\hline \multirow{2}{*}{\multicolumn{1}{c|}{ Location }} & \multirow{3}{*}{ Duration } & \multicolumn{3}{c|}{ SWH } & \multicolumn{3}{c|}{ Period } \\
\cline { 3 - 8 } & & $\gamma$ & Bias & rms & $\gamma$ & Bias & rms \\
\hline DS1 (off Goa) & May - August 2000 & 0.92 & 0.99 & 1.09 & 0.68 & 1.81 & 2.05 \\
\hline DS1 (off Goa) & May - September 2001 & 0.91 & 0.07 & 0.57 & 0.72 & 0.16 & 0.86 \\
\hline SW3 (off Goa) & May - September 2001 & 0.87 & 0.26 & 0.48 & 0.77 & 0.62 & 0.96 \\
\hline
\end{tabular}


Table 3 Statistics of the significant wave heights exceeding $2.0 \mathrm{~m}$ during southwest monsoon on various years of measurement.

\begin{tabular}{|c|c|c|c|c|c|c|c|c|c|c|}
\hline \multirow[t]{2}{*}{ Month } & \multicolumn{2}{|c|}{ May } & \multicolumn{3}{|c|}{ June } & \multicolumn{2}{|c|}{ July } & \multicolumn{2}{|c|}{ August } & \multirow{2}{*}{$\begin{array}{c}\text { September } \\
2001\end{array}$} \\
\hline & 2001 & 2004 & 2001 & 2002 & 2003 & 2001 & 2003 & 2001 & 2003 & \\
\hline $\begin{array}{l}\text { Total wave } \\
\text { heights }\end{array}$ & 237 & 247 & 178 & 124 & 240 & 145 & 246 & 218 & 118 & 230 \\
\hline $\begin{array}{c}\text { SWH }> \\
2.0 \mathrm{~m}\end{array}$ & 59 & 20 & 120 & 36 & 151 & 71 & 228 & 78 & 52 & 0 \\
\hline $\begin{array}{c}\% \text { of } \mathrm{SWH}> \\
2.0 \mathrm{~m}\end{array}$ & 24.9 & 8.1 & 67.4 & 29.0 & 62.9 & 49.0 & 92.7 & 35.8 & 44.1 & 0 \\
\hline
\end{tabular}

Table 4 Range of significant wave height (in $\mathbf{m}$ ) derived from available moored buoy data off Goa

\begin{tabular}{|c|c|c|c|c|c|}
\hline Months & \multicolumn{5}{|c|}{ Years } \\
\hline & $\mathbf{2 0 0 1}$ & $\mathbf{2 0 0 2}$ & $\mathbf{2 0 0 3}$ & $\mathbf{2 0 0 4}$ & $\mathbf{2 0 0 5}$ \\
\hline Jan & & $0.23-1.41$ & $0.33-1.15$ & $0.23-1.25$ & $0.33-1.8$ \\
\hline Feb & $0.31-1.41$ & $0.31-1.41$ & $0.38-1.50$ & $0.39-1.02$ & $0.35-1.45$ \\
\hline Mar & $0.31-1.56$ & $0.47-1.09$ & $0.30-1.87$ & $0.16-1.17$ & $0.41-1.21$ \\
\hline Apr & & & & $0.55-1.17$ & \\
\hline May & $0.55-4.30$ & $0.53-1.87$ & $0.46-1.53$ & $0.63-2.27$ & \\
\hline Jun & $0.80-3.91$ & $0.96-4.41$ & $0.78-3.80$ & & \\
\hline Jul & $1.48-2.81$ & & $1.61-3.78$ & & \\
\hline Aug & $1.56-2.97$ & & $1.26-2.52$ & & \\
\hline Sep & $0.55-1.88$ & & & & \\
\hline Oct & $0.39-1.48$ & $0.42-1.42$ & & $0.31-1.31$ & \\
\hline Nov & $0.31-0.78$ & $0.38-0.76$ & & $0.29-1.05$ & \\
\hline Dec & $0.23-0.70$ & $0.30-1.29$ & $0.23-1.02$ & $0.31-0.96$ & \\
\hline
\end{tabular}




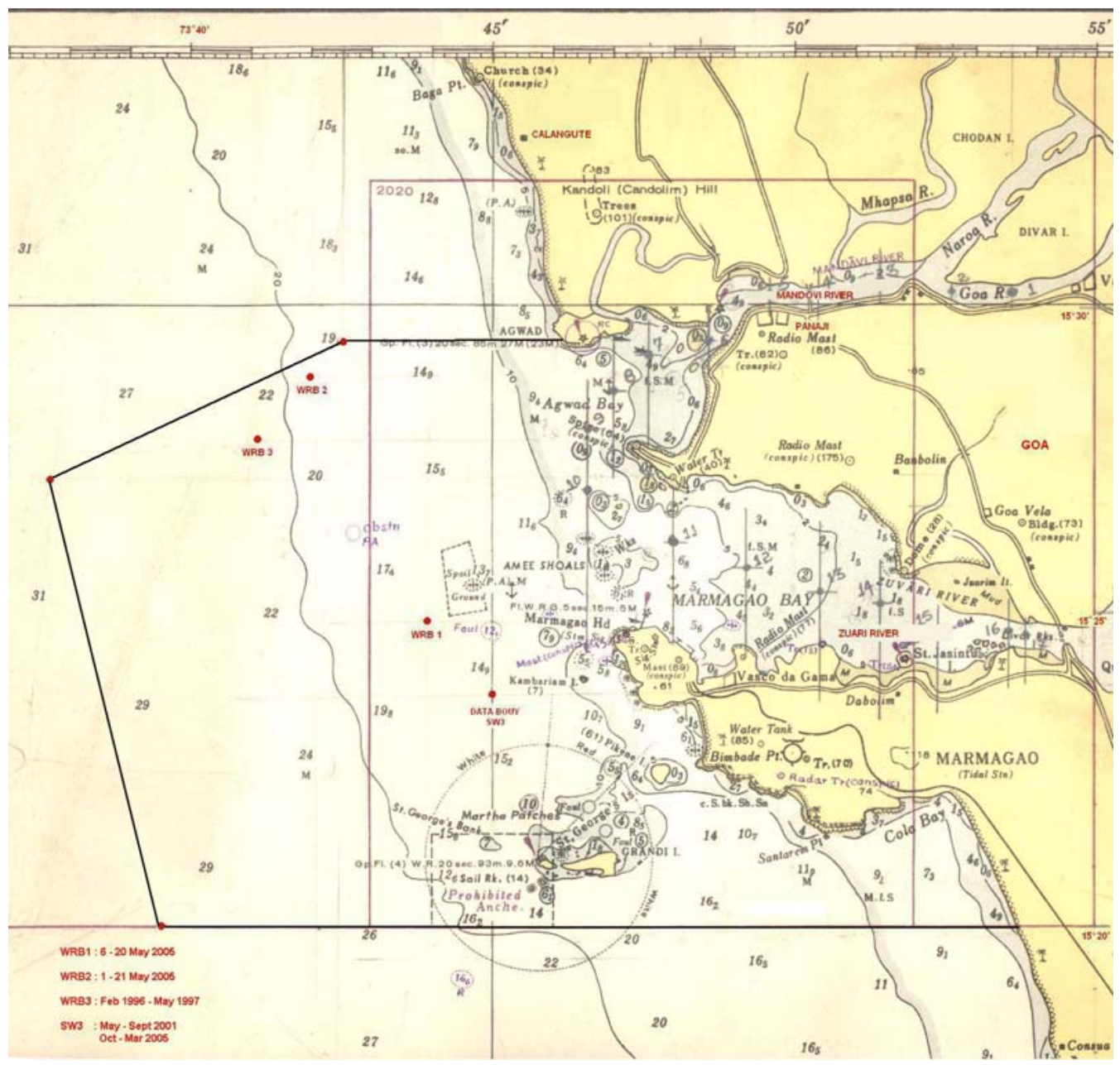

Figure 1 Study region including the locations of wave rider buoys and moored data buoy off Goa (Mormugao Port limit is marked inside). 

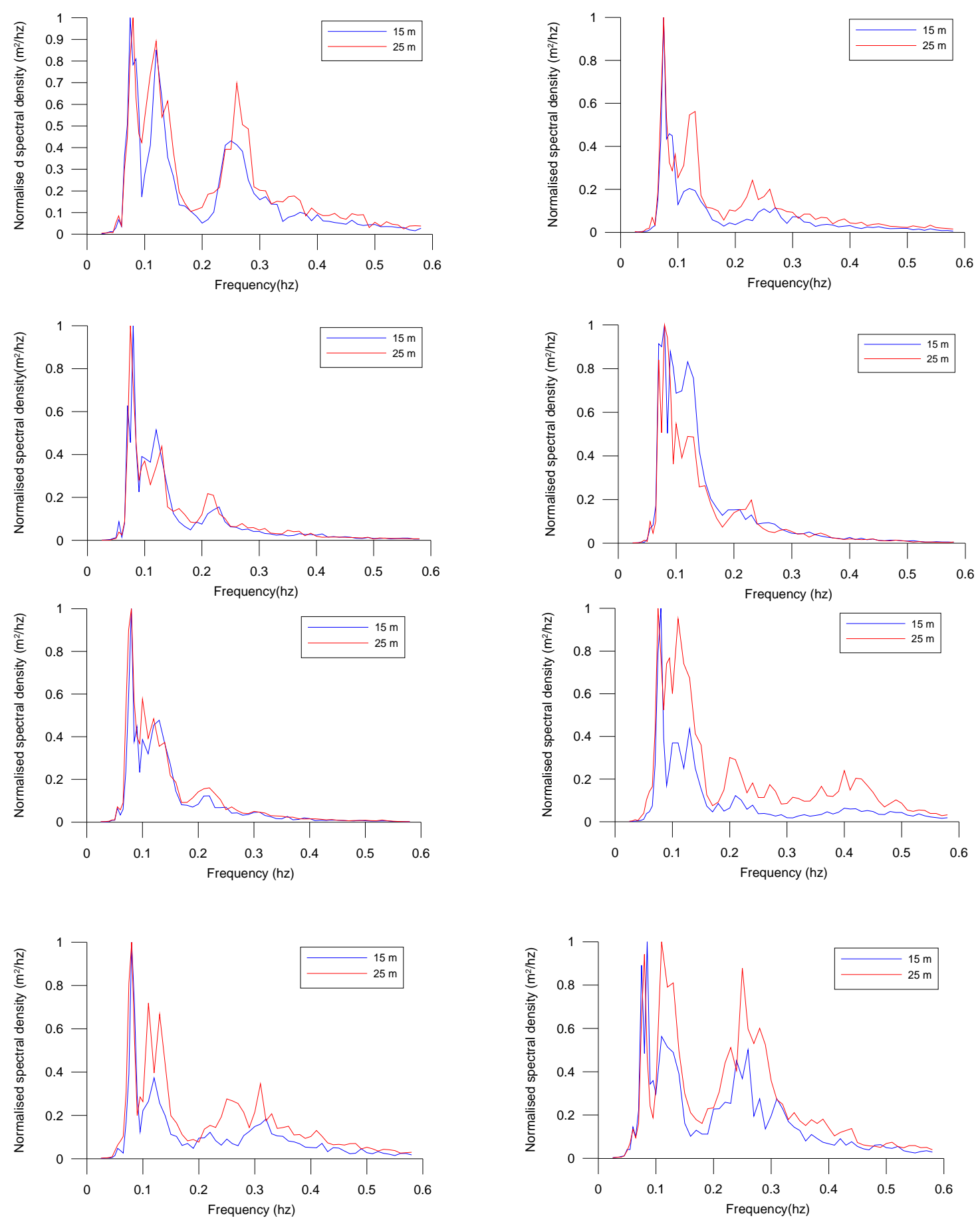

Figure 2 Typical wave spectra at 2 locations during 13 May 2005 (00 h, 03 h, 06 h, 09 h, 12 h, 15 h, 18 h, 21 h respectively). 


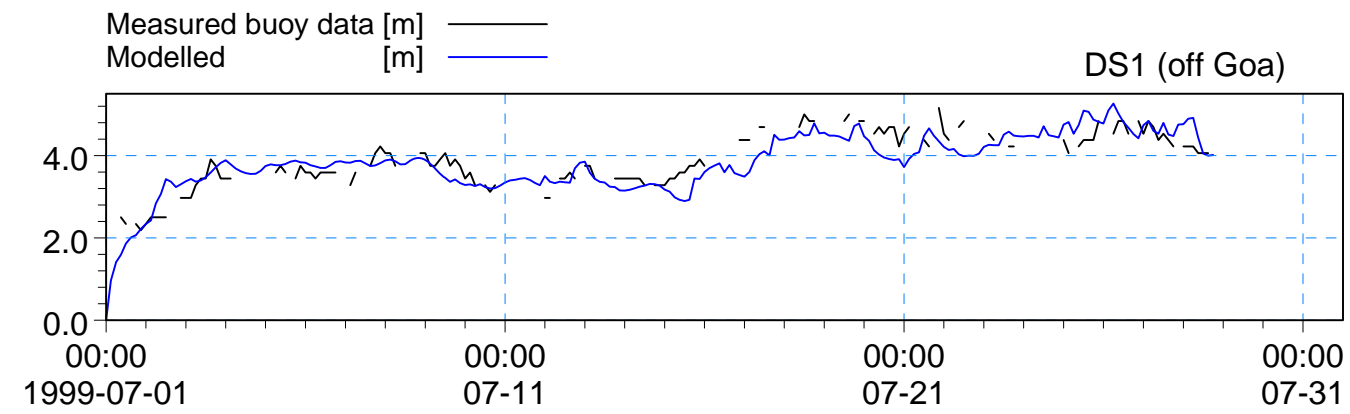

Figure 3 Comparison of significant wave height between model and buoy at deep water locations for August 1999.
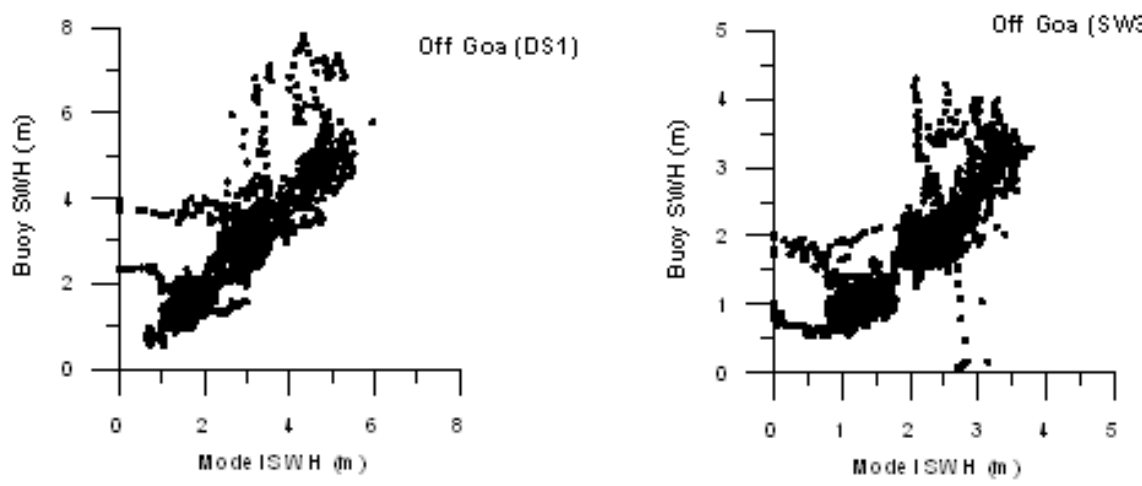

Figure 4 Comparison of significant wave height between model and buoy at deep and shallow water locations for May - September 2001

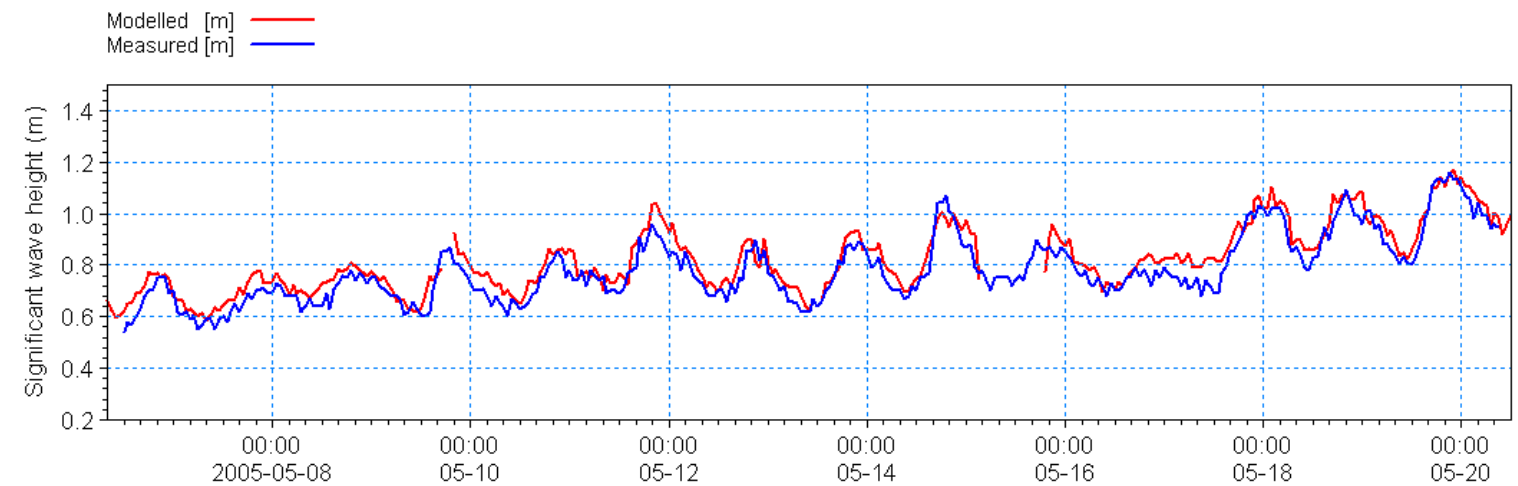

Figure 5 Comparison between measured and modelled significant wave height at $15 \mathrm{~m}$ water depth during 01 - 21 May 2005. 


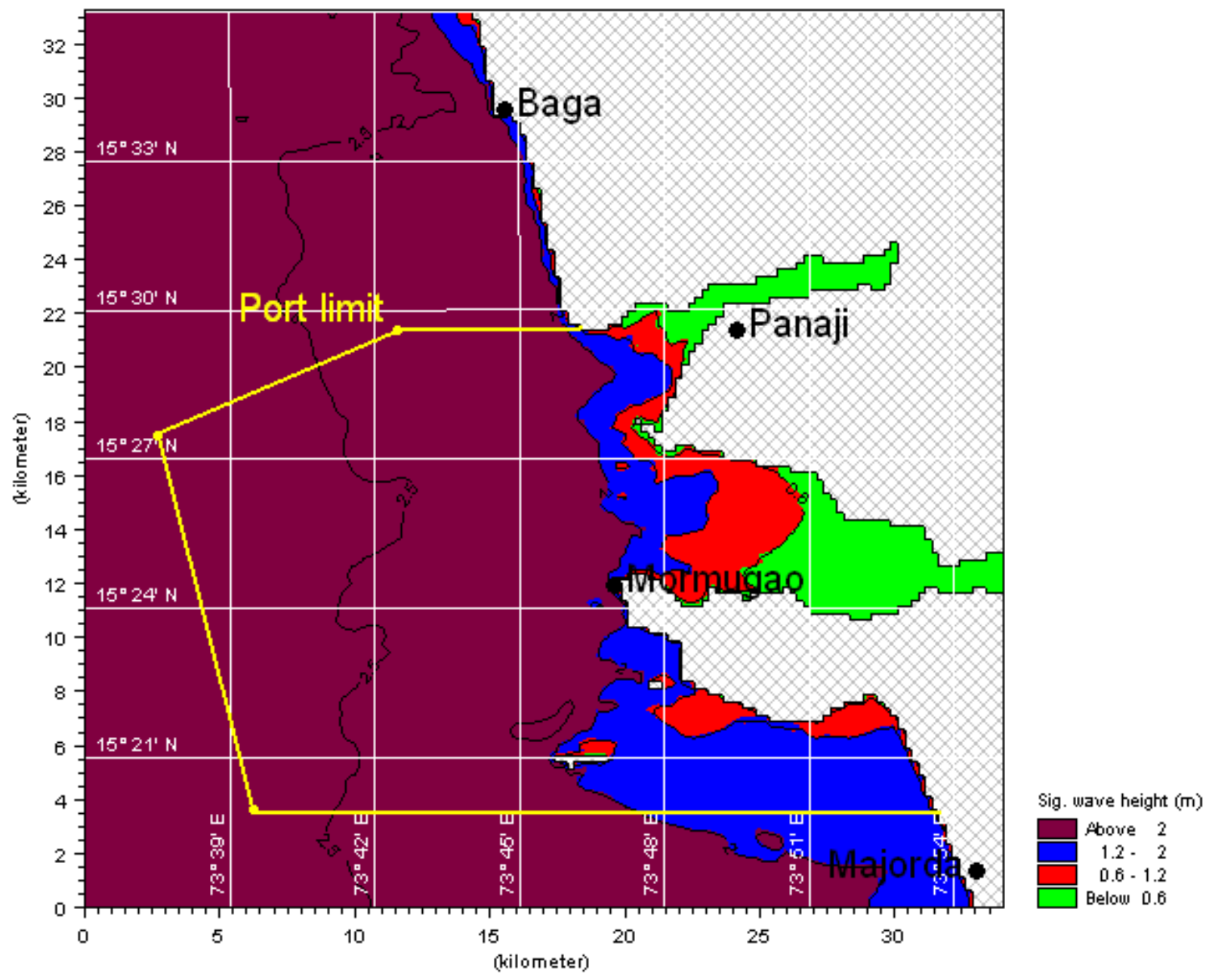

Figure 6 Typical significant wave height distribution off Mormugao Port during southwest monsoon (region showing the Mormugao Port limit are marked). 